\title{
Aggregate Suitability Assessment of Wargal Limestone for Pavement Construction in Pakistan
}

\author{
Javid Hussain ${ }^{1}$, Jiaming Zhang ${ }^{*}$, Fitriani Fitria ${ }^{2}$, Muhammad Shoaib ${ }^{3}$, \\ Hadi Hussain ${ }^{4}$, Ali Asghar ${ }^{1}$, Sadam Hussain ${ }^{4}$ \\ ${ }^{1}$ Geological Engineering, China University of Geosciences, Wuhan, China \\ ${ }^{2}$ School of Geophysics and Geomatics, China University of Geosciences, Wuhan, China \\ ${ }^{3}$ State Key Laboratory of Hydraulic Engineering Simulation and Safety, School of Civil Engineering, Tianjin University, Tianjin, \\ China \\ ${ }^{4}$ Department of Oil and Gas Engineering, China University of Geosciences, Wuhan, China \\ Email: *javid.bangash@cug.edu.cn, *zjm@cug.edu.cn
}

How to cite this paper: Hussain, J., Zhang, J.m., Fitria, F., Shoaib, M., Hussain, H., Asghar, A. and Hussain, S. (2022) Aggregate Suitability Assessment of Wargal Limestone for Pavement Construction in $\mathrm{Pa}$ kistan. Open Journal of Civil Engineering, $12,56-74$

https://doi.org/10.4236/ojce.2022.121005

Received: January 21, 2022

Accepted: February 20, 2022

Published: February 23, 2022

Copyright $\odot 2022$ by author(s) and Scientific Research Publishing Inc. This work is licensed under the Creative Commons Attribution International License (CC BY 4.0).

http://creativecommons.org/licenses/by/4.0/

\begin{abstract}
This paper presents the evaluation of the potential aggregate source for pavement construction in Pakistan. Recently the demand for construction materials has been increased significantly due to the establishment of the ChinaPakistan Economic Corridor (CPEC) Projects. Therefore, it is essential to look for new resources of construction materials along with the CPEC routes in consideration of this increasing demand. In this context, a Physical and Mechanical characterization investigation is carried out on the Permian Wargal Limestone from Zaluch Nala, Salt Range to explore their potential to utilize as construction materials. The studied samples have tolerable values for all standard engineering parameters, proposed by various national and international agencies such as AASHTO, ASTM, BS, and NHA. Furthermore, as a performance indicator of aggregate overall quality, the evaluated mechanical qualities were integrated into a single characteristic, Toughness Index (TI). The TI values also suggested that the Permian Wargal limestone aggregates meet international quality standards for pavement construction. On the basis of geotechnical testing and Toughness Index (TI), the late Permian Wargal limestone, Zaluch Nala, Salt Range, is strongly recommended as a potential aggregate resource for mega projects such as the China-Pakistan Economic Corridor (CPEC) and other construction projects.
\end{abstract}

\section{Keywords}

CPEC, Potential Aggregates, Geotechnical Properties, Toughness Index (TI), 


\section{Introduction}

Aggregate refers to any coarse to medium-grained material formed from natural (igneous, sedimentary, or metamorphic rocks) or artificial (geosynthetic aggregates) materials, depending on the source and method of use. Aggregate is the most common material used in pavement construction [1]. Aggregate mixes must sustain plastic deformation and have a high resilience modulus to withstand traffic impacts (stiffness) [2]. Aggregates must also be resistant to disintegration and weathering in situ, be free of plastic particles, and drain well [3]. Quarrying rocks and then crushing them to the proper size is the primary method of producing aggregates in Pakistan [4] [5]. Several factors to consider when selecting and recognizing the qualities of aggregates are of great importance to pavement engineers when designing pavement construction [6]. An aggregate must meet a "specification" before being used as a road-making material. Specifications from the United Kingdom or the United States are often employed.

In Pakistan, an extensive intercity network of roads and highways acts as the country's backbone, accounting for about $96 \%$ of freight movement. The extensive use of aggregate is essential to productivity and economic development in developed countries [7]. The majority of roads are in poor condition and need up up-gradation in Pakistan. In addition to other national development initiatives, new highways, roads, and other infrastructure are necessary to expedite nation-building activities [8]. Pakistan has a total area of 796,095 sq.km and a population of more than 208 million (Census - 2019) [9], with a comprehensive road network of $228.026 \mathrm{~km}$. Commercial, individual, private, and government building is in full swing, backed by Pakistan National Highways Authority (NHA) [10]. Aggregate demand is increasing due to infrastructure activities, which necessitates mapping new resources and their potential evaluation [11]. Limestone is often utilized as a raw material for aggregates, owing to its widespread availability and extensive usage in the construction and cement industries. Limestone aggregates are produced in Punjab and Khyber Pakhtunkhwa by quarrying and crushing rocks [4]. The Salt Range is dominated by Permian carbonates, located close to CPEC routs. The China-Pakistan Economic Corridor (CPEC) is a massive project that connects more than 70 nations through Pakistan's Gwadar port (Figure 1). Many long-term and short-term projects, including roads, railway lines, and fiber optic installations, are part of the CPEC project. Tunnels and bridges are also included in these lines. Furthermore, this project consists of both large and small building constructions [12] [13] [14] [15]. For such mega projects, vast reserves of the potential aggregate materials are required. In order to meet this need, various high-quality limestones are exposed at various locations along the CPEC's western route [16]. Hazara, Mansehra, Margallah Hill 
limestone, Samana Suk limestone, Kawagarh limestone, and Lockhart limestone are available in bulk amounts that can be used as potential aggregates [16]. In contrast, the central parts of the CPEC crossing through the Salt Range (Figure 1) and the Trans Indus ranges are well-stocked with Wargal limestone, Samana Suk limestone, and Sakesar limestone.

The late Permian Wargal limestone exposed near Zaluch Nala, Salt Range, was studied and evaluated to establish its potential as aggregate for construction purposes (Figure 2). The Wargal Limestone aggregates were tested for appropriateness by examining their resistance to abrasion caused by static, dynamic, permanent, and cyclic stresses. As a consequence, the following are the study objectives: 1) analyze the Wargal limestone mechanical characteristics, 2) calculate the Wargal limestone aggregates' Toughness Index (TI), 3) finally, information on the suitability of limestone in the local road and transportation sector will be provided.

\section{Geology and Stratigraphy of the Area}

The Salt Range, an active fold and thrust belt originated by the collision of the

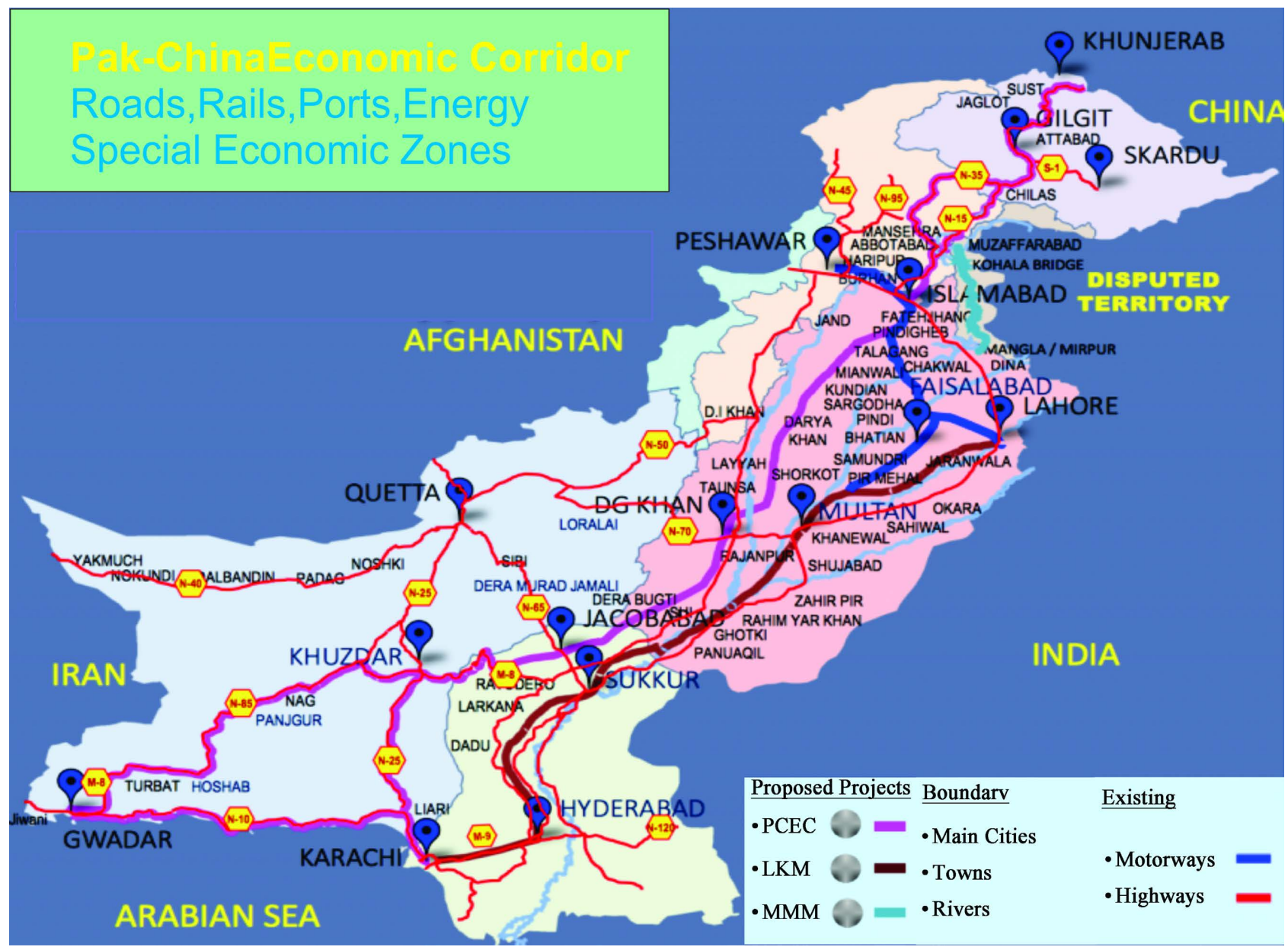

Figure 1. Pakistan-China Economic Corridor (CPEC) Mega Projects Map in Pakistan Source (National Highway Authority). 


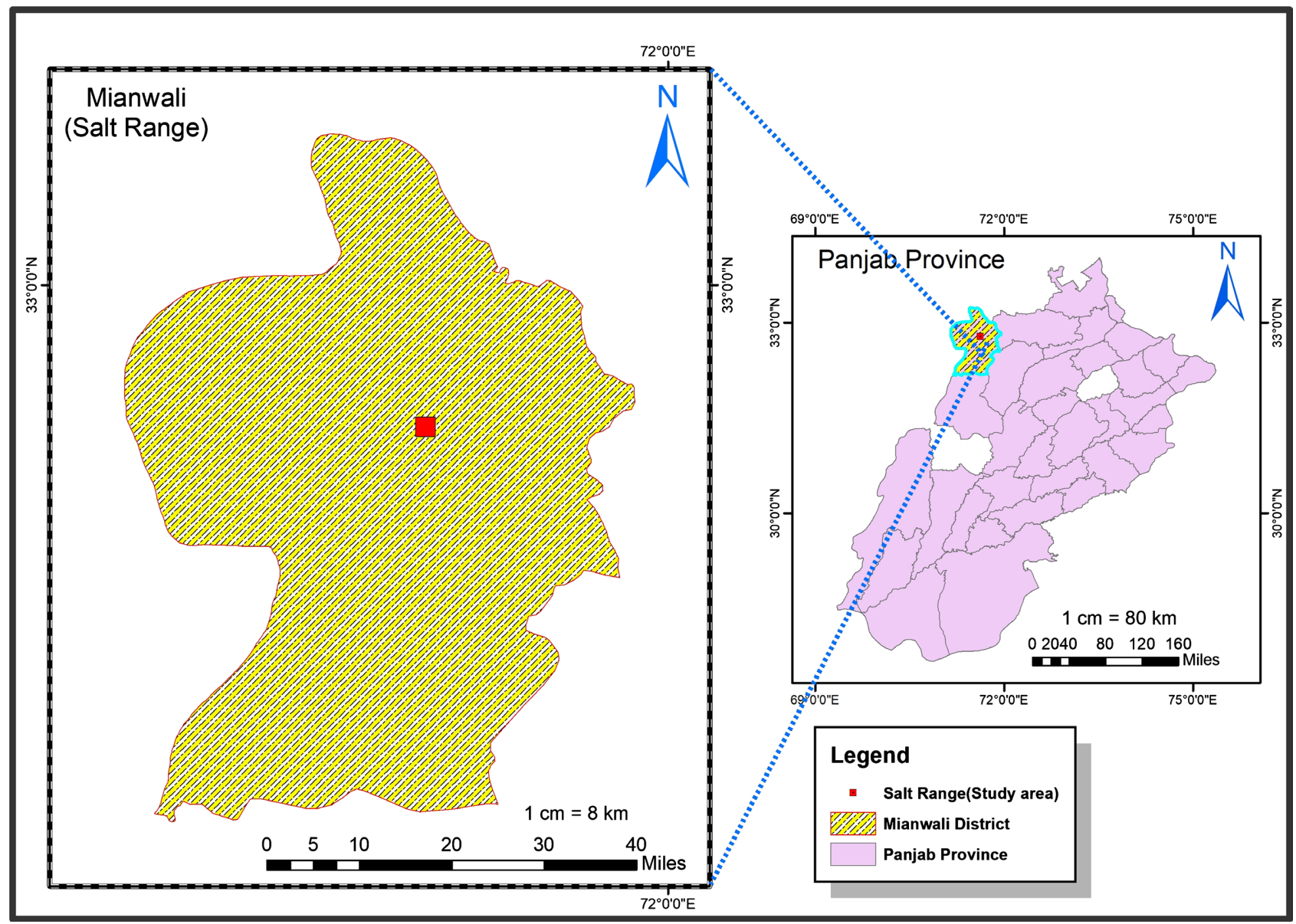

Figure 2. Location map of Wargal Limestone, Zaluch Nala, Western Salt Range, Panjab, Pakistan.

Indian and Eurasian plates, dominates the Indian Plate's northern border [17] [18]. The Indian and Eurasian plates crashed 55 million years ago because of the Indian Plate Northward drift [19] [20] [21]. The Salt Range Thrust is the Himalayan foreland system Southernmost fault and the system youngest compressional structure [22] [17]. Evaporites and overlying strata from the pre-Cambrian period cover the range front's syn-orogenic alluvium and fan material [21]. In the eastern Salt Range, the Precambrian Salt Range Formation is deposited on the younger strata (Figure 3). In contrast, the Carboniferous-Permian Nilawahan Group represents the oldest rocks exposed in the Western Salt Range [23] [24] [25]. The Salt Range contains rocks from the Precambrian to the Tertiary ages [26] [25]. The eastern, middle, and western sectors of the Salt Range include these rock units. The Salt Range Pakistan Carboniferous-Permian sequence separates the Gondwanan Lower Permian Nilawahan Group from the shallow marine Middle to Upper Permian Tethyan Zaluch Group [27] [28] [29].

Precambrian to recent strata make up the Salt Range stratigraphy (Figure 4), but the Ordovician, Silurian, Devonian, and Carboniferous strata were not found anywhere in the area [30]. The geologic succession of the Salt Range pushes out horizontally to extinction. While the Western Salt Range and the Trans Indus 


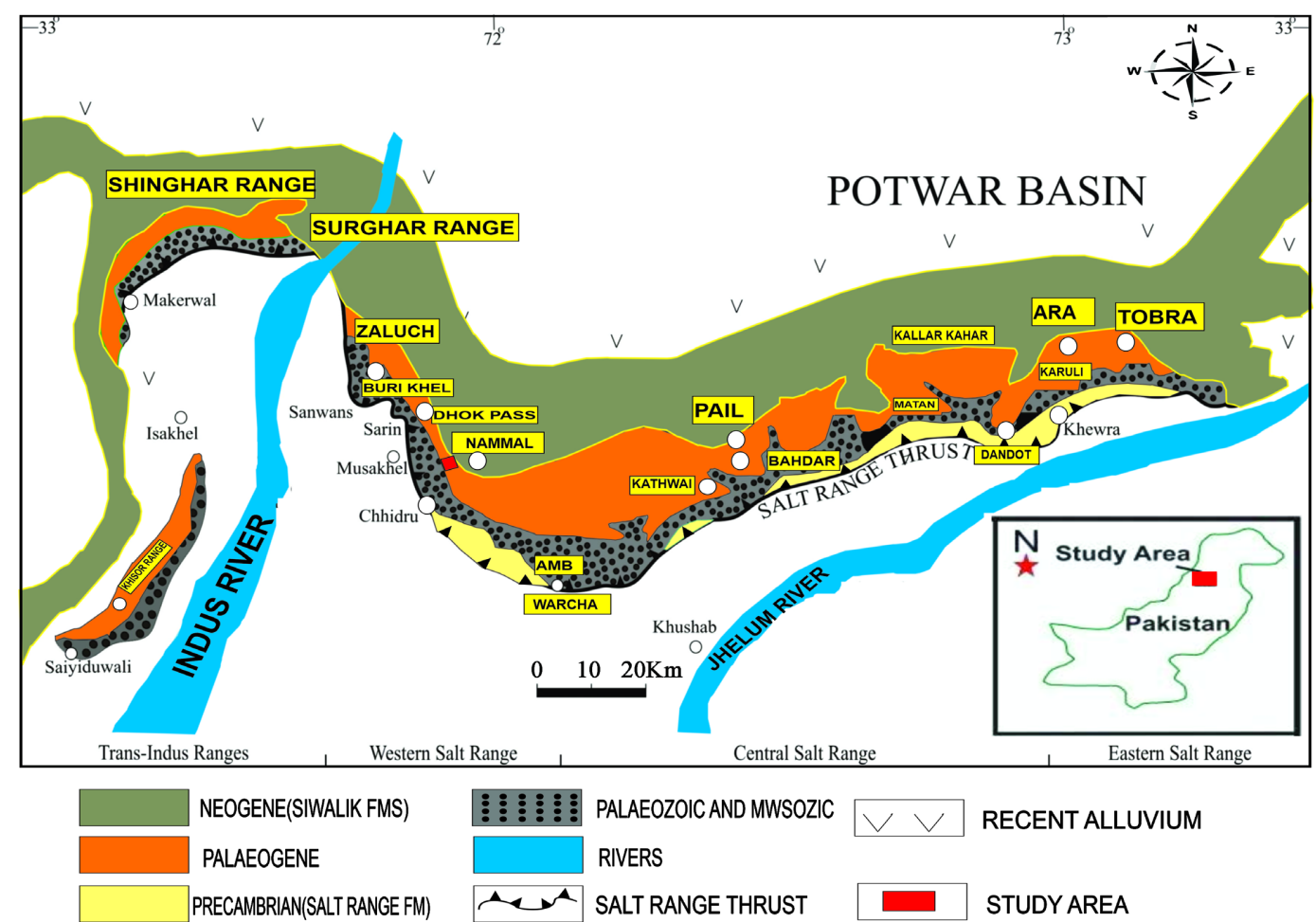

Figure 3. Geological map of Salt Range with the studied location of the Permian Wargal Limestone, Zaluch Nala, western Salt Range, Pakistan (Modified after Afzal and Butt, 2000).

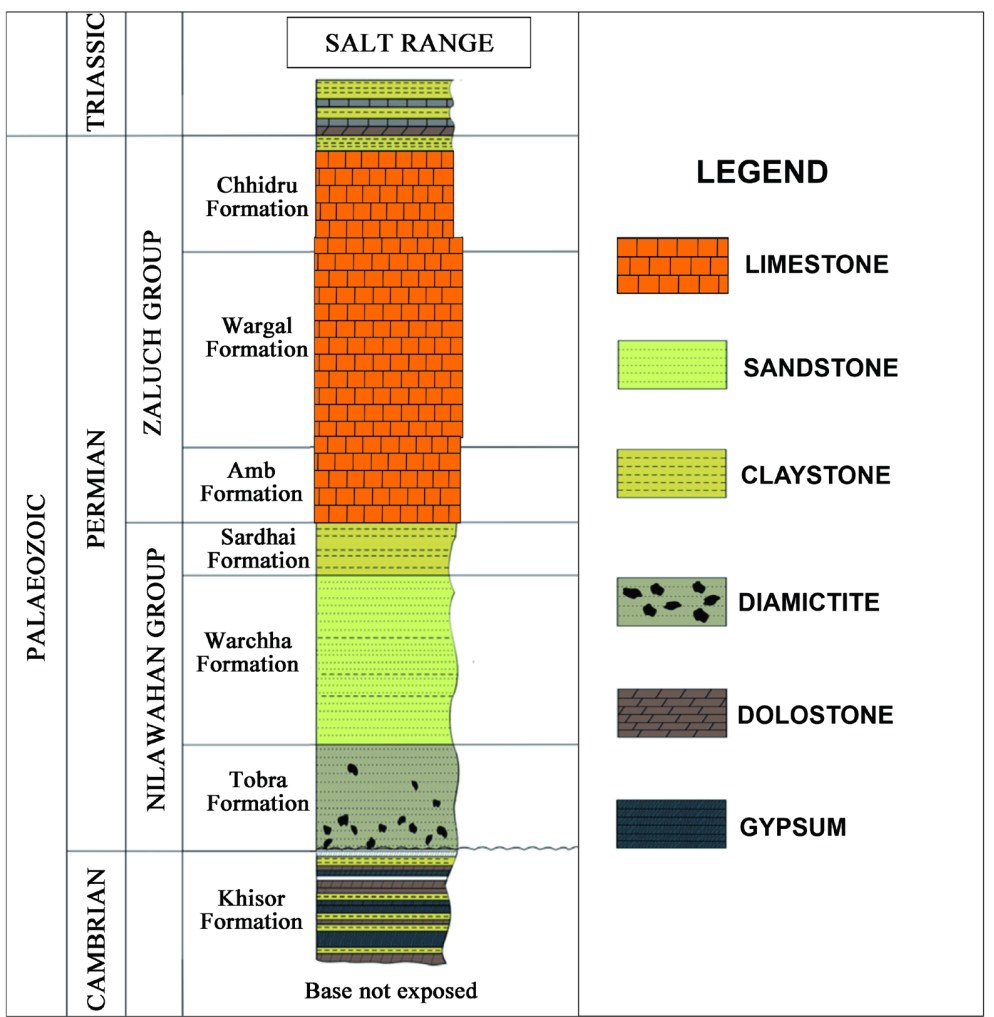

Figure 4. Simplified Carboniferous-Permian stratigraphy of the Zaluch Nala, Salt Range, Pakistan (Modified after Gee, 1989; Jan et al. 2009). 
Ranges have a well-developed Mesozoic sequence, the Triassic and perhaps all Cretaceous strata are noticeably absent from most Central and Eastern Salt Range [31]. Nilawahan Group, Tobra Formation, Dandot Formation, Warchha Sandstone, and Sardhai Formation are younger Paleozoic rocks of the lower Permain age. The Permo-Cambrian Unconformity lies between the Jhelum Group's Baghanwala Formation and the Nilawahan Group, Tobra Formation. Upper Permian Zaluch Group includes the marine siliciclastic-carbonate mixed lithofacies of the Amb Formation, Wargal Limestone, and Chhidru Limestone [31]. The PermoTriassic Boundary is marked by the Musakhel Group's Chhidru Formation and the overlying Mianwali Formation.

Nammal Gorge, western Salt Range, comprises a well-exposed portion of Wargal Limestone on an anticline faulted to the northeast (Figure 3). Wargal limestone was formerly known as "The Wargal Group", "Middle Products Limestone", and eventually as "Wargal limestone" when a Pakistani stratigraphic council formally named it. Namal gorge is the typical section of this formation. It is composed mainly of limestone and dolomite, which are almost grey. Limestone is argillaceous and crystalline, and it is often found interbedded with chert nodules and fossils in sandstone. Crystallized and fossiliferous, dolomite has a pinkishgrey color. Limestone and Dolomite comprise the lithology, composed of light to medium gray, brownish-grey, and olive-grey colors. The detailed lithology of the formation along the Zaluch Nala is about $130 \mathrm{~m}$ thick [32] [33]. The lithology changes over the thickness of Zaluch Nala.

The thickness of this formation is $183 \mathrm{~m}$ at the type locality, while the average thickness throughout the Khisor and Marwat Ranges is about $174 \mathrm{~m}$. The boundary between the Wargal limestone and the underlying Amb formation is well defined. It is situated in the formation's basal sandy limestone above the topmost shale level of the Amb formation [34]. The upper contact with the Chhidru formation is transitional. Trilobites, Gastropods, and Bivalves fossils were found. Bryozoans, brachiopods, bivalves, gastropods, nautiloids, Ammonoids, trilobites, and crinoids are abundant in the fauna. The formation dated from the mid-Permian based on the fossils [35].

\section{Methodology}

Field and laboratory studies were done to investigate the Wargal limestone and determine their aggregate potential for construction purposes. Materials for laboratory analysis were acquired from the Wargal limestone, Zaluch Nala, Salt Range. The current research is carried out for aggregate (Coarse) at the China University of Geosciences, Wuhan, China.

\subsection{Field Work}

The research area has been visited to collect representative samples for lab examination. According to [36] standards, block and crushed samples are the most common methods for collecting samples. Many characteristics were evaluated to 
determine geological suitability, workability, and economic potential, including lithology, texture, particle shape, color, bedding pattern, thickness, fauna, and lateral extension. Samples were taken from the Permian Wargal limestone, Salt Range, at equal intervals (Figure 2). All samples acquired were subjected to laboratory tests for hardness, toughness, specific gravity and porosity, shape test, chemical test, and bitumen test evaluation.

\subsection{Laboratory Tests}

The samples were subjected to various geotechnical tests using standard techniques advanced by the (ASTM-2014). Under the established standards, physi$\mathrm{cal} / \mathrm{Mechanical}$ and chemical testing was conducted on all five representative samples to select decent quality and performance-bound aggregate usage in the construction sector. It is necessary to characterize the aggregate. Physical/Mechanical and chemical testing was performed to meet the required specifications [37]. Each sample was tested five times to minimize errors and facilitate reliable results.

\subsubsection{Aggregates Hardness Tests}

Aggregate resistance to crushing and abrasion is measured by their hardness [38]. Aggregates are crushed and subjected to abrasive wear during the pavement layers' production, installation, and compaction. Pavement layers are also subjected to abrasion under traffic pressures [39]. They must withstand crushing, degradation, and disintegration to some extent. The hardness of aggregates near the pavement surface must be higher because they are subjected to increased stresses, and the aggregate can come into direct contact with the wheel. Aggregate contact stress is lower in the pavement lower layers [40]. Several significant and relevant hardness properties were examined to evaluate the quality of rock samples for usage as aggregates in pavement construction. These properties include Aggregate Crushing Value (ACV) [41], Los Angeles Abrasion (LAA) [42] test, and the 10\% Fines Value (TFV) [43].

\section{1) Crushing Value of Aggregate}

An aggregate's ability to withstand crushing under a gradually increasing compressive force is the primary goal of this test Crushing and resistance to crushing under traffic wheel load are the primary goal of this test [44] [45]. High-crushing aggregates are considered to be excellent at bearing with compressive forces [46]. ACV directly influences pavement stability; the pavement will break easily if the poor aggregate is used. The ACV is calculated using the British Standard method [47]. Strong aggregates have an ACV of about 5\%, whereas weaker aggregates have $30 \%$. The loading has a detrimental effect on the findings because weak rocks produce so many fines particles during testing. It is more appropriate to use the TFV value on such weak rock.

\section{2) Los Angles Abrasion Test}

The LAA (dry) test measures aggregates' abrasion and impact resistance. It's carried out in accordance with (T-96, 2004). LAAT limitations for aggregates are 
35 percent, 40 percent, and 50 percent of cement concrete, base course, and sub-base, respectively.

\section{3) Ten Percent Fine Value}

The TFV test determines the required force to form $10 \%$ particles from an aggregate sample held in a steel mold. It was executed in accord with [43]. The higher the value, the more difficult it is to crush the aggregate [48]. According to US and UK standards, it is not acceptable for the TFV to be less than $50 \mathrm{kN}$. It has been used to illustrate the usage of the Toughness Index. It is important to note that TFV requirements may vary from 50 to $110 \mathrm{kN}$, with a maximum of $160 \mathrm{kN}$ [3]. Equation (1) was used to find out the result.

$$
F=\frac{14 f}{m+4}
$$

where,

$f$ is the maximum force (in $\mathrm{KN}$ );

$m$ is the percentage of material passing the $2.36 \mathrm{~mm}$ test sieve at the maximum force.

Table 1 presents the data of these "hardness" tests. The table shows that Wargal limestone aggregates are suitable for usage in all pavement layers in terms of hardness.

\subsubsection{Aggregates Toughness Tests}

The aggregate's toughness refers to its ability to withstand impact forces [49]. Pavement aggregates should be hard enough to endure pounding or wheel load impact without fracturing [50]. The Aggregate Impact Value (AIV) test determines aggregates' ability to withstand a sudden impact [51]. The results are shown in Table 2. A lower AIV indicates higher impact resistance. AIV less than $10 \%$ is

Table 1. Standard base values of aggregate according to AASHTO.

\begin{tabular}{cl}
\hline Test & Base value \\
\hline LAAV & Base Course $\leq 50 \%$ \\
& Cement Concrete $\leq 16 \%$ \\
& Surface course $\leq 30 \%$ \\
& very strong $<10 \%$ \\
\hline AIV & Very strong $>10 \%-\leq 20 \%$ \\
& Wearing course $<30 \%$ \\
& Base Course $<45 \%$ \\
\hline ACV & Good aggregate $<45 \%$ \\
& Wearing course $<30 \%$ \\
\hline W.A & Good aggregate $<0.6 \%$ \\
\hline S.p Gravity & Good aggregate $\geq 2.6-\leq 2.9$ \\
\hline Soundness Test & Max $12 \%$ for Na2 and $18 \%$ for Mgso4 \\
\hline
\end{tabular}


Table 2. LA, AIV, ACV, Load to TFV, SG and TI of Analyzed Permian Wargal Limestone, Salt Range Pakistan

\begin{tabular}{ccccccc}
\hline $\begin{array}{c}\text { Sample } \\
\text { No. }\end{array}$ & $\begin{array}{c}\text { Los Angles } \\
\text { Abrasion \% }\end{array}$ & TFV (kN) & $\begin{array}{c}\text { Specific } \\
\text { Gravity \% }\end{array}$ & $\begin{array}{c}\text { Water } \\
\text { absorption \% }\end{array}$ & $\begin{array}{c}\text { Crushing } \\
\text { value \% }\end{array}$ & $\begin{array}{c}\text { Aggregate } \\
\text { Impact value \% }\end{array}$ \\
\hline 1 & 14.6 & $94.1 \pm 2.0$ & 2.55 & 0.74 & 15.96 & 11.08 \\
2 & 13.9 & $93.2 \pm 3.2$ & 2.46 & 0.85 & 14.70 & 13.67 \\
3 & 15.4 & $94.5 \pm 1.5$ & 2.99 & 0.42 & 13.01 & 11.40 \\
4 & 13.1 & $95.5 \pm 3.5$ & 2.82 & 0.80 & 14.68 & 10.41 \\
5 & 14.6 & $93.5 \pm 3.8$ & 2.85 & 0.65 & 15.00 & 12.17 \\
Average & 14.32 & $94 \pm 2.8$ & 2.73 & 0.69 & 14.67 & 11.75 \\
\hline
\end{tabular}

outstanding, AIV between $10 \%$ and $20 \%$ is acceptable, and AIV more than $35 \%$ is only suited for lower layers [52].

\subsubsection{Specific Gravity and Porosity (Water Absorption)}

Bulk specific gravity (SG) is the weight of an aggregate in air divided by the weight of an equivalent volume of distilled water. Aggregate quality and strength can be assessed using SG [3] [53]. Specific gravity and water absorption values can determine aggregate strength and water absorption capacity [54]. Aggregates used in pavements have SG values ranging from 2.6 to 2.7, with a maximum of 2.9.

The porosity of an aggregate is a measurement of the interconnecting air spaces in a particle that is evaluated by determining how much water it absorbs when submerged in water [55]. Porosity is desirable because it allows bitumen to soak into aggregate particles and produce a mechanical contact between the bitumen film and the stone particle. A porous and weathering-prone aggregate is considered a non-suitable aggregate. A weaker or poor aggregate has low specific gravity and a high water absorption rate, while a suitable aggregate has the opposite characteristics [56]. The specific gravity and water absorption are calculated using a standard approach [57]. The result of the specific gravity and water absorption is shown in Table 2.

\subsubsection{Shape Test of Aggregate}

The shape of the particles also plays a significant role in determining an aggregate's behavior and appropriateness. Internal interlock increases the stability of angular aggregate [3] [58]. Elongated or flaky material particles should not be utilized because they are difficult to compress and have a high air void content in situ. Internal friction in the aggregates impedes particle mobility, which is dictated by the shapes of the particles [59]. Particle shape properties are determined using the tests mentioned below.

\section{1) Flakiness Index (FI) Test}

The Flakiness Index measures the proportion of the sample's total weight that passes through the flaky gauge's apertures (FI). It was done according to the standards [60]. The primary purpose of this test is to assess the shape of indi- 
vidual particles, as approximately spherical particles are more robust. The total weight of the aggregate that passed through the gauge's aperture was calculated and reported as a percentage of the overall sample weight. The workability of a road is affected by deformation and breaking of aggregate under high traffic loads [54] [61]. FI value of less than 45 percent is deemed adequate for the surface and lower layers (ASTM: D-693-28).

\section{2) Elongation Index (EI) Test}

The weight of an aggregate-based sample held in an elongated gauge is used to calculate the proportion of elongated particles [16]. This test was performed by [62]. Elongated particles have low strength. The elongation index of crushed particles is 1.5 times bigger than the flakiness index [63]. An aggregate with less than 45 percent EI can be used on the surface and lower layers. Table 2 summarizes the findings of particle shape testing. Results show that aggregates from the study area are appropriate for use in both surfaces and lower layer purposes.

\subsubsection{Chemical Tests for Aggregate}

\section{Soundness Test}

Soundness quickly determines an aggregate's ability to withstand weathering and erosion. We can easily achieve aggregates by using a soundness test which can deteriorate under various weathering circumstances, such as moisture, freeze, and thaw [64]. Sodium sulfate is a common chemical used to test aggregate soundness. Weathering conditions like freezing, wetting, drying, and temperature variations damage the aggregate's structure in the field and have a direct impact on a civil construction project's life [10] [16] [65]. Aggregate quality should be rugged and durable enough to withstand weathering and erosion [4]. The specified limit for this test is $12 \%$. The results are shown in Figure 5.

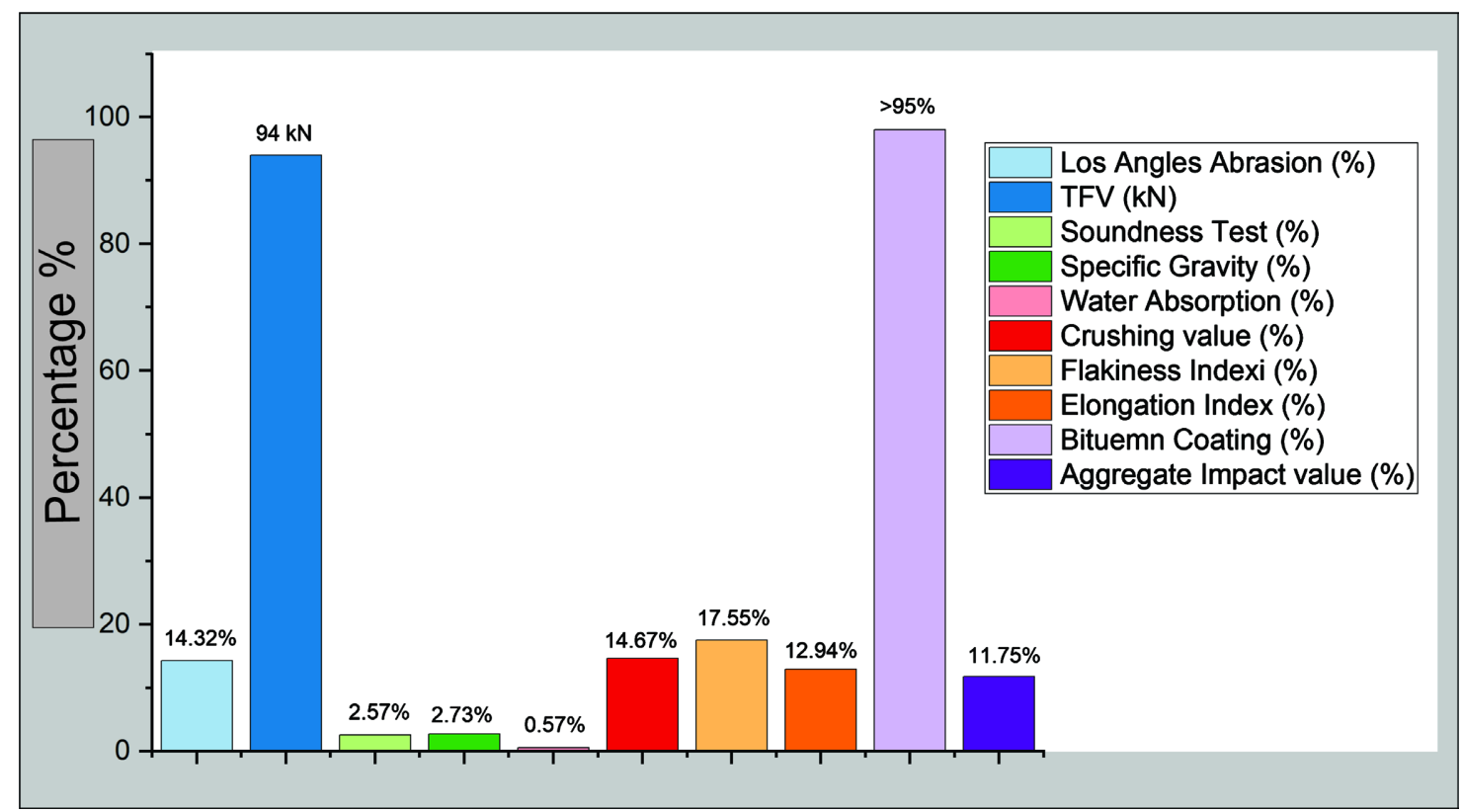

Figure 5. Engineering properties of potential aggregate resources from Zaluch Nala, Salt Range, Pakistan. 


\subsubsection{Bitumen Coating and Stripping of Aggregate}

A regulated temperature of roughly $25^{\circ} \mathrm{C}$ is necessary for this test to determine the coating properties of an aggregate with the bituminous binding material [66]. Bitumen grades 60/70 and 80/100 were employed in this test. A good blend of binder (Bitumen) and aggregate components will be obtained in aggregate with increased coating and striping value, which eventually strengthens and extends the life of any civil building [67]. Under the action of water and moisture, asphalt aggregate must maintain a thin coating of bitumen on its surface [61]. The test results are shown in Figure 5.

\subsubsection{Toughness Index (TI)}

The mechanical properties of the aggregates were better represented by [3] establishing a classification of aggregates based on a mechanical index; it is based on the measured values of LA, AI, AC, TF, and SG (Figure 6).

The method for calculating TI is outlined below. Table 3 lists the hardness values used to standardize aggregate hardness data for this research. The British Standard specifies the maximum values for each attribute. The goal is to define

Table 3. Aggregate specification Source: Based on Kamal et al. (2006).

\begin{tabular}{ccc}
\hline TI Range & Rating & Use \\
\hline$>97$ & Very Good & Road Surfacing and Base \\
$95-97$ & Good & Base and Subbase \\
$90-95$ & Fair & Subbase Only \\
$<90$ & Poor & Use with caution \\
\hline
\end{tabular}

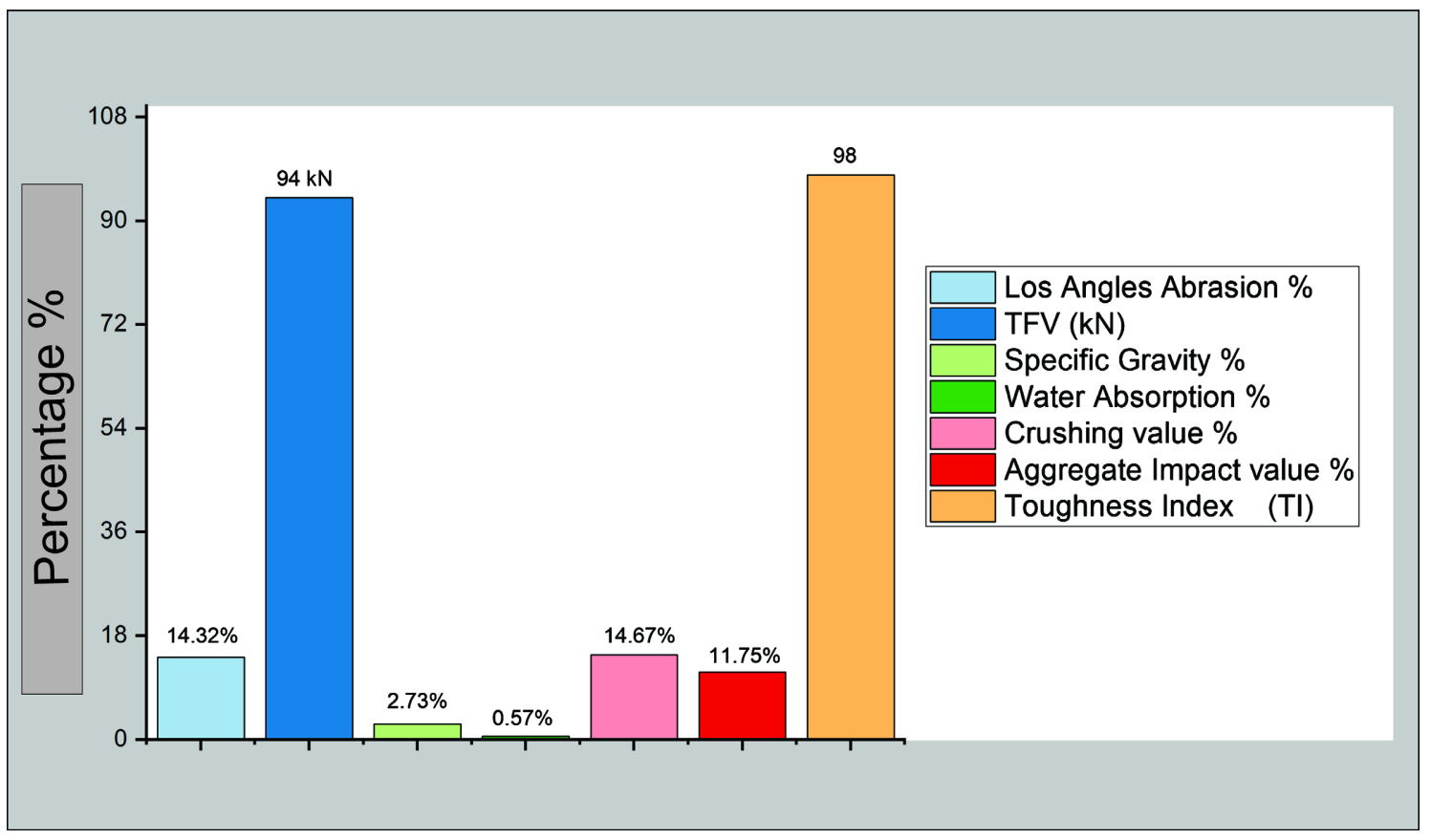

Figure 6. Toughness Index of Aggregate from Zaulch Nala, Salt Range Pakistan. 
a TI on a scale of 1 - 100 to specify the aggregate's total strength from a single source [3]. As in the case of CBR, the calculated TI may be more than 100. The TI is calculated from the given Equation (2).

$$
\mathrm{TI}=\frac{A+B+C+D+E}{5}
$$

where,

$$
\begin{gathered}
A=1.1 \times \frac{\mathrm{SG}}{2.9} \times 100 \\
B=\mathrm{IF} \mathrm{ACV} \leq 30=100 \text { OR } \\
B=\mathrm{IF}(\mathrm{ACV}>30)=\frac{100-\mathrm{ACV}}{(100-30) 100} \\
C=\mathrm{IF} \mathrm{TFV} \geq 50=100 \text { OR } \\
C=\mathrm{IF}(\mathrm{TFV}<50)=\frac{\mathrm{TFV}}{50 \times 100} \\
D=\frac{100-\mathrm{LAAV}}{100-15 \times 100} \\
E=\mathrm{IF} \mathrm{AIV} \leq 30=0.9 \times 100 \text { OR } \\
E=\mathrm{IF}(\mathrm{AIV}>30)=0.9 \times \frac{100-\mathrm{AIV}}{(100-30) 100}
\end{gathered}
$$

On this basis, the TI for aggregates in this research has been determined and is shown in Figure 6.

\section{Result and Discussion}

Results of various tests on Wargal Limestone aggregate are compared to the standard values of AASHTO, ASTM, and the National Highway Authority Pakistan, established by Road Research and Material Testing Institute Punjab (Table 1). To assess whether Wargal limestone is appropriate for road aggregate, the standard values are applied and compared to the analyzed values of the limestone.

The standard value for the LA test for Sub Base is $50 \%$, the base course is $40 \%$, and the concrete is $35 \%$. The results obtained for the LAA test are $14.32 \%$ (Table 2), which is within the acceptable range of concrete (Table 1). The assessed Wargal limestone samples are permitted as concrete, base course, sub base, and surface course (Table 1). The Wargal limestone has a low LAA value, is rated the hardest aggregate, and is best suited for base and surface courses. The maximum ACV for the Base course should be $45 \%$, and the maximum ACV for the Surface course should be $35 \%$; the result of the tested samples is $14.67 \%$ (Table 2). Based on these values, the analyzed value is within acceptable ranges. Wargal limestone can be used as a base and surface course, subbase, and concrete aggregate (Table 1). The TFV test shows the aggregates' needed load to create $10 \%$ fines [3]. The Wargal limestones required a load more than $90 \mathrm{kN}$, which is within the per- 
missible range of the stipulated maximum in US and UK regulations. The standard values for AIV are characterized as follows: $10 \%$ extremely strong, $>10 \%$ $20 \%$ strong, $>20 \%-30 \%$ acceptable for the road surface, while the maximum limit for base course is $45 \%$. According to AIV, the analyzed sample value was recorded $11.75 \%$ (Table 2), and it is suited for road surface and Base Course and fall within the range of strong aggregate (Table 1). Wargal limestone is the hardest aggregate suited for use in a landslide-prone environment because it has a low AIV. The water absorption test value was recorded $0.57 \%$ (Table 2) for the analyzed limestone sample, and the standard value should be $\leq 0.60 \%$ (Table 1 ). Wargal limestone demonstrates the lowest absorption limit. According to the results, Wargal limestone is robust and non-porous. Specific gravity indicates a rock's strength, and high specific gravity values indicate a strong rock. The recommended Specific gravity value falls in the range of $\geq 2.6-\leq 2.9$ Table 1 , with examined samples value was recorded 2.73 Table 2, Wargal limestone is recommended as an excellent aggregate based on comparisons.

Based on Equation (1), Toughness Index TI values for aggregate samples in the present study have been calculated and are presented in Figure 6. Toughness index (TI), a unique value, can be used as a performance indicator for the aggregates [3]. According to classification Table 3, aggregates with the TI values less than 90 can be considered poor quality and, therefore, can be either avoided or used with proper caution. In this study, the values of TI were found $>90$ and are recommended as very good aggregate in quality, and it is suitable for pavement construction purposes.

The average value of the flakiness index is $17.55 \%$ Figure 5 . These findings are within the specified ranges, indicating that the aggregate under investigation could be utilized in concrete and asphalt. Elongation index test average results value was recorded of $12.94 \%$ Figure 5 . The findings are well within the standard specified limit (15 percent Max), indicating that the aggregate under consideration could be utilized safely in asphalt and cement concrete. According to ASTM standards, the recommended value for Soundness Test (ST) is an average weight loss on each sieve of no more than $12 \%$; the assessed value of Wargal limestone was $2.57 \%$ Figure 5 . Wargal limestone is resistive to freezing and thawing cycles of weathering because values are less than 12 percent Table 1 , based on the result the Wargal limestone recommended for aggregate potential. The stripping Value of all the samples of Wargal limestone was below $5 \%$ using 80/100-grade bitumen, and the coating value was recorded above 95\% Figure 5 . The values of coating and striping of bitumen are comparable with international standards and designate Wargal limestone as an excellent source for potential aggregate.

All Engineering Test Results and toughness Index (TI) show that the studied samples of Wargal limestone excellently qualify the acceptable ranges of these engineering parameters as allowed by different Agencies like AASHTO (2009), ASTM (2004), BS (1990), and NHA (1998) for the base course, sub-base course, 
asphalt, and cement concretes. The values of these parameters are excellently comparable with other good quality aggregates sources exposed in Margalla Hill, Kirana complex, and adjacent areas in Pakistan [54] [61].

\section{Conclusion}

The paper emphasizes the potential of Wargal limestones, which are located in the Salt Range of Pakistan, to be exploited as an aggregate source for engineering projects. Various laboratory tests were performed to establish the physical and mechanical properties of the Wargal limestone. Values of physical parameters were compared mutually with BS and ASTM standards for their qualification as an aggregate source for the construction industry. The physical, chemical and mechanical properties of Wargal limestone are well in accordance with international standards and therefore highly recommended for pavement and transportation uses. The Wargal limestone aggregate showed excellent bitumen affinity, so it's strongly recommended for road surfacing. The Toughness Index (TI), represents a unified mechanical property to classify aggregates for pavement construction, and it highly recommends the Wargal limestone as the best potential aggregate source. Our analysis and laboratory tests suggest that all physical properties of the Wargal limestone are within the acceptable ranges and it is strongly recommended as a potential aggregate resource for mega projects such as the China-Pakistan Economic Corridor (CPEC) and other local infrastructure and industrial zones. Limestone is easily available and transportable to many areas. Open-pit excavation is a simple way to mine limestone. Mining should be carried out in an environmentally sustainable way.

\section{Future Work}

Unconfined compression test (UCS), Ultimate Tensile test (UTS), and other lab experiments are recommended for the better analysis of Wargal limestone. In order to utilize Wargal limestone in all kinds of construction work, more inquiry into the occurrence history of aggregate samples, their structural behavior, and Petrographic analysis is advised. Remote sensing-based mapping is needed to distinguish between the various lithological differences in the region (i.e., Limestone, Dolomite, Sandstone, etc.). The expansion of crushing operations in the region will result in a massive quantity of potential aggregate for development.

\section{Acknowledgments}

The authors would like to say thanks to all those whose help directly and indirectly.

\section{Conflicts of Interest}

The authors declare no conflicts of interest regarding the publication of this paper. 


\section{References}

[1] Bilqees, R. and Shah, T. (2007) Industrial Applications of Limestone Deposits of Kohat, NWFP: A Research towards the Sustainability of the Deposits. Biological Sciences-PJSIR, 50, 293-298.

https://v2.pjsir.org/index.php/biological-sciences/article/download/1012/559

[2] Little, D.N. (1998) Evaluation of Structural Properties of Lime Stabilized Soils and Aggregates. National Lime Association, Arlington.

[3] Kamal, M.A., Sulehri, M.A. and Hughes, D.A.B. (2006) Engineering Characteristics of Road Aggregates from Northern Pakistan and the Development of a Toughness Index. Geotechnical \& Geological Engineering, 24, 819-831. https://doi.org/10.1007/s10706-005-6610-9

[4] Rehman, G., Zhang, G., Rahman, M.U., Rahman, N.U., Usman, T. and Imraz, M. (2020) The Engineering Assessments and Potential Aggregate Analysis of Mesozoic Carbonates of Kohat Hills Range, KP, Pakistan. Acta Geodaetica et Geophysica, 55, 477-493. https://doi.org/10.1007/s40328-020-00301-9

[5] Mouhamed, B.B. and Qiu, Y. (2017) Evaluation of Physical and Mechanical Properties of Quarry Stones in the Southern Republic of Benin. Journal of Sustainable Development of Transport and Logistics, 2, 61-66.

https://doi.org/10.14254/jsdtl.2017.2-1.6

[6] Price, B. (2003) High Strength Concrete. In: Advanced Concrete Technology Processes, Elsevier Ltd., Amsterdam. https://doi.org/10.1016/B978-075065686-3/50289-5

[7] Benhabib, J. and Spiegel, M.M. (1994) The Role of Human Capital in Economic Development Evidence from Aggregate Cross-Country Data. Journal of Monetary Economics, 34, 143-173. https://doi.org/10.1016/0304-3932(94)90047-7

[8] Ahsan, N. and Gondal, M.M.I. (2016) Aggregate Suitability Studies of Limestone Outcrops in Dhak Pass, Western Salt Range, Pakistan. International Journal of Agriculture and Applied Sciences (Pakistan), 4, 69-75. https://www.researchgate.net/publication/273433983

[9] Goujon, A., Wazir, A. and Gailey, N. (2020) Pakistan: A Population Giant Falling Behind in Its Demographic Transition. Population Societies, 4, 1-4. https://www.researchgate.net/publication/340503174 https://doi.org/10.3917/popsoc.576.0001

[10] Gondal, M.M.I., Ahsan, N. and Javid, A.Z. (2008) Evaluation of Shaki Sarwar and Rajan Pur Aggregates for Construction in Southern Punjab Province, Pakistan. Geological Bulletin of the Punjab University, 43, 101-107. http://pu.edu.pk/images/journal/geology/PDF-FILES/Vol_43_101-107.pdf

[11] Hassan, E.U.L., Hannan, A. and Rashid, M.U.R. (2020) Resource Assessment of Sakesar Limestone as Aggregate from Salt Range Pakistan Based on Geotechnical Properties. International Journal of Hydrology, 4, 24-29. https://doi.org/10.15406/ijh.2020.04.00222

[12] Bhattacharjee, D. (2015) China Pakistan Economic Corridor. https://doi.org/10.2139/ssrn.2608927

[13] Shah, S.A.H. (2018) Strategy for Mineral Sector Development in Pakistan. Ministry of Planning, Development \& Reform, Islamabad, 1-24.

[14] Ali, M. (2018) Pakistan's Quest for Coal-Based Energy under the China-Pakistan Economic Corridor (CPEC): Implications for the Environment. Environmental Science and Pollution Research, 25, 31935-31937.

https://doi.org/10.1007/s11356-018-3326-y 
[15] Khattak, S.A., Qadir, A., Daud, H., Shehzad, K., Yasir, M. and Abubakar, M. (2021) Terrace Soil Suitability for Highway Construction: Case Study in Lesser Himalaya (CPEC Project E-35), North Pakistan. International Journal of Economic and Environmental Geology, 12, 54-59.

[16] Rehman, S.U., Ahmed, M., Hasan, F., Hassan, S., Rehman, F. and Ullah, M.F. (n.d.) Aggregate Suitability Studies of Middle Jurassic Samana Suk Formation Exposed at Sheikh Budin Hill, Marwat Range, Pakistan. Journal of Biodiversity and Environmental Sciences, 12, 159-168.

https://innspub.net/jbes/aggregate-suitability-studies-middle-jurassic-samana-suk-f ormation-exposed-sheikh-budin-hill-marwat-range-pakistan

[17] Ghazi, S., Ali, S.H., Sahraeyan, M. and Hanif, T. (2015) An Overview of Tectonosedimentary Framework of the Salt Range, Northwestern Himalayan Fold and Thrust Belt, Pakistan. Arabian Journal of Geosciences, 8, 1635-1651. https://doi.org/10.1007/s12517-014-1284-3

[18] Jaumé, S.C. and Lillie, R.J. (1988) Mechanics of the Salt Range-Potwar Plateau, Pakistan: A Fold-and-Thrust Belt Underlain by Evaporites. Tectonics, 7, 57-71. https://doi.org/10.1029/TC007i001p00057

[19] Molnar, P. and Tapponnier, P. (1977) The Collision between India and Eurasia. Scientific American, 236, 30-41. https://doi.org/10.1038/scientificamerican0477-30

[20] Baker, D.M., Lillie, R.J., Yeats, R.S., Johnson, G.D., Yousuf, M. and Zamin, A.S.H. (1988) Development of the Himalayan Frontal Thrust Zone: Salt Range, Pakistan. Geology, 16, 3-7. https://doi.org/10.1130/0091-7613(1988)016<0003:DOTHFT>2.3.CO;2

[21] Yeats, R.S., Khan, S.H. and Akhtar, M. (1984) Late Quaternary Deformation of the Salt Range of Pakistan. Geological Society of America Bulletin, 95, 958-966. https://doi.org/10.1130/0016-7606(1984)95<958:LQDOTS>2.0.CO;2

[22] Grelaud, S., Sassi, W., de Lamotte, D.F., Jaswal, T. and Roure, F. (2002) Kinematics of Eastern Salt Range and South Potwar Basin (Pakistan): A New Scenario. Marine and Petroleum Geology, 19, 1127-1139. https://doi.org/10.1016/S0264-8172(02)00121-6

[23] Jan, I.U., Shah, A., Stephenson, M.H., Iqbal, S., Hanif, M., Wagreich, M. and Hussain, H.S. (2016) The Sedimentology of the Lower Permian Dandot Formation: A Component of the Gondwana Deglaciation Sequence of the Salt Range, Pakistan. Rivista Italiana Di Paleontologia e Stratgrafia, 122, 75-90.

[24] Craig, J., Hakhoo, N., Bhat, G.M., Hafiz, M., Khan, M.R., Misra, R., Pandita, S.K., Raina, B.K., Thurow, J. and Thusu, B. (2018) Petroleum Systems and Hydrocarbon Potential of the North-West Himalaya of India and Pakistan. Earth-Science Reviews, 187, 109-185. https://doi.org/10.1016/j.earscirev.2018.09.012

[25] Gee, E.R. and Gee, D.G. (1989) Overview of the Geology and Structure of the Salt Range, with Observations on Related Areas of Northern Pakistan. Geological Society of America Special Paper 232, 95-112. https://doi.org/10.1130/SPE232-p95

[26] Bilal Malik, M., Hussain, M., Faisal Meraj, A., Afgan, S. and Shahzad Rathore, P.W. (2020) Application of Seismic Attribute Analysis and Subsurface Structure Interpretation for Hydrocarbon Prospects: A Case Study of Indus Basin, Pakistan. In: SEG Technical Program Expanded Abstracts 2020, Society of Exploration Geophysicists, Houston, 1196-1200. https://doi.org/10.1190/segam2020-3427362.1

[27] Stephenson, M.H., Jan, I.U. and Sa'ad Zeki, A. (2013) Palynology and Correlation of Carboniferous-Permian Glacigene Rocks in Oman, Yemen and Pakistan. Gondwa- 
na Research, 24, 203-211. https://doi.org/10.1016/j.gr.2012.06.005

[28] Jan, I.U. and Stephenson, M.H. (2011) Palynology and Correlation of the Upper Pennsylvanian Tobra Formation from Zaluch Nala, Salt Range, Pakistan. Palynology, 35, 212-225. https://doi.org/10.1080/01916122.2011.573964

[29] Wardlaw, B.R. and Pogue, K.R. (1995) The Permian of Pakistan. In: The Permian of Northern Pangea, Springer, Berlin, 215-224. https://doi.org/10.1007/978-3-642-78590-0_11

[30] Khan, S., Ahmad, S., Hanif, M., Jan, I.U., Swati, M.A.F., Khan, S. and Saboor, A. (2014) Lithofacies, Paleoenvironments and Sequence Stratigraphic Modelling of the Wargal Limestone: Implication for Reservoir Characterization in the Salt Range, Northwest, Pakistan. Journal of Himalayan Earth Sciences, 47, 41. https://www.researchgate.net/publication/289466306

[31] Shah, S.M.I. (1977) Stratigraphy of Pakistan. GSP Memoirs, 22, 399.

[32] Shehzad, S., Alam, I., Mehmood, S. and Masood, F. (2018) Diagenetic History and Microfacies Analysis of Upper Permian Wargal Limestone in the Central Salt Range, Pakistan. Pakistan Journal of Scientific \& Industrial Research Series A: Physical Sciences, 61, 163-172. https://doi.org/10.52763/PJSIR.PHYS.SCI.61.3.2018.163.172

[33] Sohn, I.G., Kummel, B. and Teichert, C. (1970) Early Triassic Marine Ostracodes from the Salt Range and Surghar Range, West Pakistan. In: Kummel, B. and Teichert, C., Eds., Stratigraphic Boundary Problems. Permian and Triassic of West Pakistan, University of Kansas Press, Kansas, 193, 206.

[34] Ali, S.K., Janjuhah, H.T., Shahzad, S.M., Kontakiotis, G., Saleem, M.H., Khan, U., Zarkogiannis, S.D., Makri, P. and Antonarakou, A. (2021) Depositional Sedimentary Facies, Stratigraphic Control, Paleoecological Constraints, and Paleogeographic Reconstruction of Late Permian Chhidru Formation (Western Salt Range, Pakistan). Journal of Marine Science and Engineering, 9, 1372.

https://doi.org/10.3390/jmse9121372

[35] Nakazawa, K., Kapoor, H.M., Ishii, K., Bando, Y., Okimura, Y. and Tokuoka, T. (1975) The Upper Permian and the Lower Triassic in Kashmir, India. Memoirs of the Faculty of Science, Kyoto University. Series of Geology and Mineralogy, 42, 1-106. http://hdl.handle.net/2433/186607

[36] ASTM, D. (n.d.) D 75-87 Standard Practice for Sampling Aggregates. ASTM International, West Conshohocken.

[37] Thomas, C., De Brito, J., Cimentada, A. and Sainz-Aja, J.A. (2020) Macro- and Micro-Properties of Multi-Recycled Aggregate Concrete. Journal of Cleaner Production, 245, Article ID: 118843. https://doi.org/10.1016/j.jclepro.2019.118843

[38] Ugur, I., Demirdag, S. and Yavuz, H. (2010) Effect of Rock Properties on the Los Angeles Abrasion and Impact Test Characteristics of the Aggregates. Materials Characterization, 61, 90-96. https://doi.org/10.1016/j.matchar.2009.10.014

[39] Arshad, H. and Qiu, Y.J. (2012) Evaluation of Dina Aggregates for Pavement Construction in Pakistan. Advanced Materials Research, 548, 239-242. https://doi.org/10.4028/www.scientific.net/AMR.548.239

[40] Wang, H. and Al-Qadi, I.L. (2009) Combined Effect of Moving Wheel Loading and Three-Dimensional Contact Stresses on Perpetual Pavement Responses. Transportation Research Record, 2095, 53-61. https://doi.org/10.3141/2095-06

[41] Standard, B. (n.d.) 812: Part 110: 1990. Methods for Determination of Aggregate Crushing Value. BSI, London.

[42] T-96, A. (2004) Standard Method of Test for Resistance to Degradation of Small-Size 
Coarse Aggregate by Abrasion and Impact in the Los Angeles Machine, Standard Specifications for Transportation Materials, and Methods for Sampling, and Testing. Part-2A: Tests. AASHTO.

[43] Part, B. S. 812 (1990) Methods for Determination Often Percent Fines Value (TFV). BS 812: Part 111. BSI, London.

[44] Manju, R., Sathya, S. and Sheema, K. (2017) Use of Plastic Waste in Bituminous Pavement. International Journal of ChemTech Research, 10, 804-811. https://www.researchgate.net/publication/320243162

[45] Indraratna, B., Salim, W. and Rujikiatkamjorn, C. (2011) Advanced Rail Geotechnology-Ballasted Track. CRC Press, Boca Raton. https://doi.org/10.1201/b10861

[46] West, G. (1996) Alkali-Aggregate Reaction in Concrete Roads and Bridges. Thomas Telford, London. https://doi.org/10.1680/aricrab.20696

[47] 110, B. S. 812 (1990) Testing Aggregate: Methods for Determination of Aggregate Crushing Value. British Standard, London.

[48] Poon, C.S. and Chan, D. (2006) Paving Blocks Made with Recycled Concrete Aggregate and Crushed Clay Brick. Construction and Building Materials, 20, 569-577. https://doi.org/10.1016/j.conbuildmat.2005.01.044

[49] Mahmoud, E., Masad, E. and Nazarian, S. (2010) Discrete Element Analysis of the Influences of Aggregate Properties and Internal Structure on Fracture in Asphalt Mixtures. Journal of Materials in Civil Engineering, 22, 10-20. https://doi.org/10.1061/(ASCE)MT.1943-5533.0000005

[50] Jethro, M.A., Shehu, S.A. and Olaleye, B. (2014) The Suitability of Some Selected Granite Deposits for Aggregate Stone Production in Road Construction. The International Journal of Engineering and Science, 3, 75-81. https://www.researchgate.net/publication/322530283

[51] Kolawole, A.A., Abdulazeez, M., Omoniyi, I.G.E.O. and Awu, B.S. (2019) Engineering Characterization of Rocks from the Minna Granitic Formation as Pavement Construction Aggregates. Journal of Geography, 7, 27-32. https://doi.org/10.15640/jges.v7n1a3

[52] 812-112, B. S. (1990) Methods of Determination of Aggregate Impact Value (AIV). Technical Information Services Department, CNL Technical Information.

[53] Tutumluer, E., Mishra, D. and Butt, A.A. (2009) Characterization of Illinois Aggregates for Subgrade Replacement and Subbase. http://hdl.handle.net/2142/45969

[54] Khan, Z.K. (2000) Study of the Geology of Kirana Group, Central Punjab and Evaluation of Its Utilization and Economlc Potential as Aggregate. University of the Punjab, Lahore. http://173.208.131.244:9060/xmlui/handle/123456789/8835

[55] Quattrone, M., Cazacliu, B., Angulo, S.C., Hamard, E. and Cothenet, A. (2016) Measuring the Water Absorption of Recycled Aggregates, What Is the Best Practice for Concrete Production? Construction and Building Materials, 123, 690-703. https://doi.org/10.1016/j.conbuildmat.2016.07.019

[56] Ismail, S. and Ramli, M. (2013) Engineering Properties of Treated Recycled Concrete Aggregate (RCA) for Structural Applications. Construction and Building Materials, 44, 464-476. https://doi.org/10.1016/j.conbuildmat.2013.03.014

[57] ASTM, C. (n.d.) 127-07 Standard Test Method for Density. Relative Density (Specific Gravity), and Absorption of Coarse Aggregates.

[58] Lees, G. and Kennedy, C.K. (1975) Quality, Shape and Degradation of Aggregates. Quarterly Journal of Engineering Geology, 8, 193-209. 
https://doi.org/10.1144/GSL.QJEG.1975.008.03.03

[59] Zhang, G., Hui, S., Li, W. and Sui, W. (2020) Experimental Investigation on Pouring Aggregate to Plug Horizontal Tunnel with Flow Water. Water, 12, 1763.

https://doi.org/10.3390/w12061763

[60] Institution, B.S. (1989) Testing Aggregates. Part 105: Methods for Determination of Particle Shape. Section 105.1: Flakiness Index. British Standards Institution, London.

[61] Gondal, M.M.I., Ahsan, N. and Javaid, A.Z. (2009) Engineering Properties of Potential Aggregate Resources from Eastern and Central Salt Range, Pakistan. Geological Bulletin of Punjab University, 44, 97-103.

http://pu.edu.pk/images/journal/geology/PDF-FILES/Vol_44_97-103.pdf

[62] 1990, B. S. 812-105. 2. (1990) Testing Aggregates-Part 105: Methods for Determination of Particle Shape-Section 105.2 Elongation Index of Coarse Aggregate. British Standards Institution, London.

[63] Kwan, A.K.H., Mora, C.F. and Chan, H.C. (1999) Particle Shape Analysis of Coarse Aggregate Using Digital Image Processing. Cement and Concrete Research, 29, 1403-1410. https://doi.org/10.1016/S0008-8846(99)00105-2

[64] Mitchell, D.W. and Marzouk, H. (2007) Bond Characteristics of High-Strength Lightweight Concrete. ACI Structural Journal, 104, 22. https://doi.org/10.14359/18429

[65] Kazi, A. and Al-Mansour, Z.R. (1980) Influence of Geological Factors on Abrasion and Soundness Characteristics of Aggregates. Engineering Geology, 15, 195-203. https://doi.org/10.1016/0013-7952(80)90034-4

[66] Gorkem, C. and Sengoz, B. (2009) Predicting Stripping and Moisture Induced Damage of Asphalt Concrete Prepared with Polymer Modified Bitumen and Hydrated Lime. Construction and Building Materials, 23, 2227-2236. https://doi.org/10.1016/j.conbuildmat.2008.12.001

[67] Aastho, T.P. (2013) 101-14. UL, Estimating Damage Tolerance of Asphalt Binders Using the LAS. American Association of State and Highway Transportation Officials, Washington DC. 